\title{
Topographic embedding of MOR18-2 in the mouse olfactory bulb
}

\author{
J Soelter ${ }^{1 *}$, J Schumacher ${ }^{2}$, H Spors ${ }^{2}$, M Schmuker ${ }^{1,3}$ \\ From 1st International Workshop on Odor Spaces \\ Hannover, Germany. 4-7 September 2013
}

Mice are exceptional in their ability to capture their chemical environment, mapping the olfactory world into a basic sensory representation with over one thousand different types of chemical sensors, that is, olfactory sensory neurons (OSNs). OSNs of each type converge in the olfactory bulb onto exclusive distinct physiological areas called glomeruli. The glomeruli constitute the first relay station of olfactory stimulus representation in the mouse brain. Thus, the stimulus induced glomerular input pattern spatially embodies an important part of the sensory representation in the olfactory bulb. Still, topographic organization principles (chemotopy, tunotopy) are under debate. One reason might be that investigation are, due to experimental limitations, only performed on stimuli sets in the size of one hundred odors. But this represents only a tiny snapshot of the vast amount of molecules in the olfactory world and topographic relationships might be disguised in the incomplete representation of molecular receptive ranges (MRR). Therefore we investigated the problem with the MOR18-2 glomerulus as point of reference: First we determined it's MRR. Then, based on a measurement set covering this MRR, we elucidated the topographic embedding. It shows that MOR18-2 is embedded in a hierarchy of patchy tunotopic domains.

This work was funded by DFG grants SCHM2474/1-1 and 1-2.

\section{Authors' details}

${ }^{1}$ Neuroinformatics \& Theoretical Neuroscience, FU Berlin, Germany. ${ }^{2}$ Department of Molecular Neurogenetics, MPI of Biophysics, Frankfurt, Germany. ${ }^{3}$ Bernstein Center for Computational Neuroscience, Berlin, Germany.

Published: 16 April 2014

${ }^{1}$ Neuroinformatics \& Theoretical Neuroscience, FU Berlin, Germany Full list of author information is available at the end of the article
doi:10.1186/2044-7248-3-S1-P19

Cite this article as: Soelter et al:: Topographic embedding of MOR18-2 in the mouse olfactory bulb. Flavour 2014 3(Suppl 1):P19.
Submit your next manuscript to BioMed Central and take full advantage of:

- Convenient online submission

- Thorough peer review

- No space constraints or color figure charges

- Immediate publication on acceptance

- Inclusion in PubMed, CAS, Scopus and Google Scholar

- Research which is freely available for redistribution
() Biomed Central

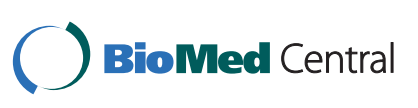

